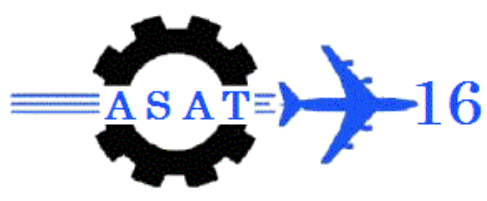

\title{
NUMERICAL STUDY ON THE EFFECTS OF NUMBER OF BLADES ON THE PERFORMANCE OF TORQUE CONVERTERS
}
A. Khafagy ${ }^{1}$
I. Saleh ${ }^{1}$
I. Elsherief ${ }^{1}$

\begin{abstract}
Number of blades of torque converter elements plays an important role in the design and performance of torque converters. In this paper, effects of the number of pump and turbine blades on the performance of torque converters are investigated numerically at different speed ratios, using a commercial software, ANSYS-CFX. Two torque converters, with the same outer diameter of $245 \mathrm{~mm}$, were studied. Number of blades of the first torque converter is (32, 36 and 17) and for the second torque converter is (41, 37 and 17) for the pump, turbine and stator respectively. Blade shape and angles for the torque converter elements are the same. Numerical simulation results were compared and verified with the available literature and experimental results. A satisfactory agreement is presented between numerical and experimental results. Results showed that increasing the number of the blades of both of the pump and the turbine caused an increase of both of pump and turbine torque while the stall torque ratio is decreased and the coupling point occurred at lower speed ratio. Also, increasing the number of blades caused the maximum efficiency to be decreased. This may be explained by the change of slip factor of different number of blades as well as the effect of friction on shock losses. The study showed that there is an optimum number of blades required to improve the performance of torque converter.
\end{abstract}

\section{KEYWORDS}

Computational Fluid Dynamics (CFD), Torque Converter.

\footnotetext{
${ }^{1}$ Egyptian Armed Forces
} 


\section{INTRODUCTION}

An automotive torque converter, as shown in Figure 1, is a complex turbomachine used to transfer power from a vehicle engine to its transmission. It also multiplies the engine torque at a low engine speed, which improves a vehicle launching performance. Torque converter keeps an engine rotating at an idling speed without a need of clutch and also reduces rotational disturbances at a low engine speed.

Torque converter consists of a mixed-flow pump connected to the engine crankshaft, a mixedflow turbine attached directly to the transmission, and an axial flow stator attached to a stationary housing through a one-way clutch. The pump adds angular momentum to the fluid and forces it radially towards the turbine. The turbine blades receive the fluid from the pump and turn it radially inward. The turbine absorbs the angular momentum and drives the transmission input shaft. The flow exists from the turbine to the stator blades which accelerates the fluid and redirects it towards the pump. The fluid adds a torque to the pump equal to the stator reaction. Hence the engine torque transferred to the pump and the reaction torque transferred by the fluid to the pump are both transmitted to torque converter turbine. This mechanism is called torque multiplication.

The performance parameters of torque converter are torque ratio, efficiency and dimensionless torque groups. All of these parameters are expressed against speed ratio. Speed ratio is defined as the ratio of turbine angular speed to the pump angular speed. The torque ratio is expressed as the ratio of turbine torque (output torque) to the pump (input) torque. Maximum torque multiplication occurs when the turbine speed equals zero, i.e. largest speed difference between the pump and the turbine. Torque converter efficiency computed from the product of torque ratio and speed ratio. The efficiency of a torque converter is one of the most important factors that influence fuel economy. Improved torque converter performance can lead to reduction in fuel consumption. Another important parameter is the capacity factor and sometimes is called $\mathrm{K}$-factor. $\mathrm{K}$-factor equal the pump speed in rpm dived by the square root of pump torque.

The flow in turbomachinery components is three dimensional, highly viscous and unsteady with secondary flows. The flow in torque converter is higher complex than any other turbomachine for several reasons. First, the flow field changes dramatically over the range of operating conditions. Specifically, incidence angles to the leading edge of the blades for all of the components change from small values (less than $90^{\circ}$ ) to large values (higher than $90^{\circ}$ ) over the operating range. Second, the flow is highly three-dimensional as it is turned in the blade passages in two directions. Thus, as in any turbomachine, blade slip becomes a 
problem, especially at off-design operating conditions. Also, in addition to turning in the tangential and radial directions, the flow is turned by 180 in the transverse axial direction in both the pump and the turbine in a relatively short distance. Namely, the flow enters these two components in the axial direction, is rapidly turned toward the radial direction, and rapidly turned back into the reverse axial direction. Also the complexity comes from it is a closed loop flow. Thus, the torque converter is a very complex mixed flow variety of hydraulic turbomachine. Also the torque converter operates at different design conditions with different incidence angles for each torque converter element.

To improve the performance of a torque converter it is necessary to understand the flow field inside it. In the last few years, Computational Fluid Dynamics (CFD) played an important role in understanding the flow inside torque converters with the improved commercial CFD codes and high computational resources. In this paper the flow inside two different torque converters was studied using CFD code ANSYS-CFX at different operating conditions.

\section{LITERATURE WORK.}

A number of researches have studied the flow features in a torque converter employing numerical and experimental methods. By and Lakshminarayana $[1,2]$ measured average static pressure on the blades of the torque converter pump and turbine. Their results showed that the primary factor responsible for the static pressure rise in the pump is the centrifugal force and the static pressure distribution is generally poor at the blade core section. Brun and Flack [3] employed a laser velocimetry in a Plexiglas torque converter to obtain detailed velocity profiles inside torque converter turbine. They presented flow data of a torque converter at speed ratio of 0.065 and 0.8 .

Fujitaniet. al. [4] computed the flow within a torque converter by assuming that the inlet boundary condition of each element is equivalent to the outlet boundary condition of the upstream-side element. Abe et. al. [5] conducted numerical analysis of the flow field by adopting the steady-interaction technique to connect the boundaries between the neighboring elements. They did not include a turbulence model. By et al. [6] developed a three dimensional, incompressible, viscous flow code to predict the flow field in a torque converter pump using the pseudo-compressibility method. They analyzed the secondary flow patterns in the pump and compared them with experimental results. Cigarini and Sreenadh [7] performed a three dimensional simulation of the fluid flow in an automotive torque converter by applying steady interaction technique implemented in the CFD program STAR-CD. They used the standard k- $\varepsilon$ turbulence model in their analysis. The torque ratio showed a good 
agreement when compared with the experimental data. They concluded that the used code can simulate the fluid flow with sufficient accuracy. Dong et. al. [8] conducted CFD simulation to develop new stators to increase torque ratio at turbine speed equal zero and $\mathrm{K}$-factor improvement. The results showed that there is an increase in the stall torque ratio for newly developed torque converter. They concluded that the main reasons for this increase in torque ratio were the increased stator exit angle and decreased stator losses. Schweitzer and Gandham [9] had described some of the work done to validate CFD results and gave examples of ways in which CFD is used in the torque converter design process. Based on the validation studies, they concluded that CFD could be used as a design and analysis tool for torque converter development.

The literature reveals the need for flow field analysis in improving the design and performance of a torque converter. Due to the complex structure, very few computational studies have been reported previously and since these are performed by car manufactures, the detailed flow investigations results are not published. In the present work, numerical simulation are carried out to provide a detailed fluid flow in two torque converter with different size and configuration. An effort is also made to understand the flow in details at different operating conditions.

\section{GEOMETRIC MODEL}

The present study was carried out for torque converter with $245 \mathrm{~mm}$ outer diameter and is manufactured by General Motors Cooperation (GM). This torque converter will be denoted as GM-245 throughout this paper. The blades of both of the pump and turbine of GM-245 torque converter is manufactured from sheet metal with uniform thickness of $1 \mathrm{~mm}$ while the stator is manufactured with a special shape cast blade. The numbers of blades are 32, 36 and 17 in the pump, turbine and stator, respectively.

In order to study the effect of number of blades on the torque converter performance, the number of blades of both the pump and the turbine was increased with the same original diameter, $245 \mathrm{~mm}$, and the same blade shape. The modified torque converter will be donated TC-modified.

The number of blades of TC-modified is 41,37 and 17 for the pump, turbine and stator, respectively.

\section{THE NUMERICAL MODEL.}

The commercial code ANSYS-CFX is a Finite Volume based CFD package with second order accuracy in space and time and an algebraic multi-grid technique. ANSYS-CFX is an 
integrated software system capable of solving diverse and complex three-dimensional fluid flow problems. It is a multi-grid based fluid flow solver provides solutions for fluid flow problems in complex geometries.

The boundary conditions were specified at CFX-Pre. The Multiple Reference Frame technique was used to model the torque converter elements that are rotating relative to one another. The fluid is defined as Automatic Transmission Fluid (ATF). The fluid is incompressible with constant physical properties with density of $(816) \mathrm{kg} / \mathrm{m}^{3}$, and viscosity of $(0.0024) \mathrm{N} \mathrm{s} / \mathrm{m}^{2}$ at temperature of $60^{\circ} \mathrm{C}$. The numerical analysis used the standard $\mathrm{k}-\varepsilon$ model for turbulence. The first order upwind scheme was used for discretization between the inlet and outlet. The residual were converged to a minimum of $1 \times 10^{-4}$.

All simulations were run using stage averaging between the torque converter elements to obtain steady state solutions. The effect of grid density on the numerical results was investigated.

Numerical investigation has been carried out to study the effects of number of blades on the performance of torque converters at different speed ratios. The numbers of blades of the GM$245 \mathrm{~mm}$ torque converter are 32, 36 and 17 for the pump, turbine and stator, respectively. The numbers of blades of the modified torque converter, will be denoted as TC-Modified, are 41, 37 and 17 for the pump, turbine and stator, respectively. The blade shape for the three torque converter elements is the same (angles and blade thickness). The pump speed is $1000 \mathrm{rpm}$.

\section{RESULTS AND DISCUSSION}

The flow field inside a torque converter was simulated under three different speed ratios $(0.0$, 0.6 and 0.8 ). The pump of the torque converter was assigned a constant speed of $1000 \mathrm{rpm}$.

The calculated torque is the integral of the pressure over the element blade. The pump torque added to the stator torque is examined to be equal to the turbine torque. Also, the mass flow rate outputted from each element is examined to be equal the next element flow rate.

\subsection{Grid dependence for GM-245 torque converter}

The effect of grid size on CFD results is presented in Figure 2 and Figure 3 for GM-245 torque converter. Figure 2 shows that the calculated pump torque for different grid size. Figure 3 shows the calculated torque ratio for different grid size. Figure 2 and Figure 3 show that the calculated pump torque and torque ratio is the same for medium and fine grid sizes. This indicates that the CFD results are not sensitive to the change in the grid size. The medium size grid is used for simulation.

\subsection{Performance Characteristics.}

Figure 4 shows the performance characteristics of a GM-245 torque converter compared with the experimental results. Figure shows a good agreement between the numerical results and experimental measurements. The numerical solution is over predicting the torque ratio at 
speed ratio over 0.6 until the coupling point. This results in over predicting of the torque converter efficiency.

The pump torque of TC-Modified torque converter is higher than GM-245 torque converter as shown in Figure 5 which indicate that increasing the number of pump blades caused an increase in pump torque. Figure 6 shows a comparison between turbine torque for the two torque converters. TC-Modified torque converter shows a higher turbine torque than GM-245 torque converter.

Increasing the number of blades of both the pump and turbine decreased the torque ratio as shown in Figure 7. The coupling point is decreased from 0.88 to 0.8 . The efficiency of both torque converters is equal until speed ratio of 0.5, as shown in Figure 8. At higher speed ratio, the maximum (peak) efficiency of TC-Modified torque converter is lower than that of GM245 torque converter. This indicates that increasing the number of blades of both the pump and turbine caused a decrease in the maximum efficiency.

Figure 9 shows a comparison between pump and turbine head against speed ratio. Turbine and pump head of TC-Modified torque converter are lower than GM-245 torque converter at speed ratios higher than 0.2. The head difference, (pump head - turbine head), which is the energy required to circulate the flow, has been predicted numerically (Figure 10). Increasing the pump and turbine blade caused an increase in the head difference at high speed ratio (higher than 0.6) as shown in Figure 10. This increase may be attributed to increasing of the slip factor. The head difference is high at low speed ratio with high flow rate. As the flow rate is decreased the head difference is decreased.

Figure 11 shows the calculated flow rate against speed ratio. Figure 11 shows that increasing the number of blades caused an increase of the flow rate. This difference is high at speed ratio 0.0 and decreases as the speed ratio increase until the coupling point. Increasing the number of blades caused an increase in the flow rate at various speed ratios. This is due to the effect of incidence angle at the blade entrance.

The pressure along a streamline midway between the hub and shroud of torque converter elements for different speed ratio are shown in Figure 12 through Figure 14. The pressure is investigated along the torque converter elements because it is very important in studying cavitation. The streamwise location for pump is from 0 to 1 . The turbine stremwise from 1 to 2 and the stator is from 2 to 3 . At speed ratio of 0.0 , the pressure inside the turbine is increased for the two torque converters, then it start to drop after streamwise of 1.5 for TCModified torque converter and 1.7 for GM-245 torque converter. The pressure at the turbine exit is higher than the pressure at the turbine inlet for both of the torque converters. According 
the basic theory of turbo-machinery, static pressure drop along a streamwise is caused by a centrifugal force, static pressure drop due to flow acceleration, and / or pressure loss due to viscous effects. The static pressure drop due to centrifugal force is negligible since the turbine is fixed. Most of the static pressure drop is attributed in torque converter turbine to the acceleration of the relative flow and the viscous loss. The pressure inside the stator is dropped from the stator inlet along the streamwise direction. The pressure inside stator, after 0.75 streamwise, starts to increase until the stator exit. Guide vanes (torque converter stator) are designed in converged-diverged sectional shape in order to increase the pressure at the pump entrance.

At speed ratio of 0.6, the pressure inside TC-Modified is higher than the pressure inside GM245 for all the torque converter elements. At speed ratio of 0.8 , the pressure for the two torque converters is equal. At all speed ratios, there is an increase of pressure at turbine entrance due to gap area effect between the turbine and pump. This is affected by increasing the number of blades of the pump and turbine.

There is an increase of pressure at turbine entrance due to gap area effect. This is affected by increasing the number of blades of the pump then the flow enters the turbine causes a high pressure. The pressure is studied along the torque converter elements because it is very important in studying cavitation.

Guide vanes (torque converter stator) are designed in converged-diverged sectional shape in order to increase the pressure at the pump entrance. Increasing the number of the blades caused an increase in the flow rate at various speed ratio. This is due to the effect of incidence angle at the blade entrance.

\section{CONCLUSIONS}

Numerical investigation of the flow field inside two torque converters was presented to study the effect of number of the blades on the performance of torque converters. Numerical simulation showed a good agreement with pervious published experimental results.

Increasing the number of the blades of both the pump and turbine decreased the coupling point speed. The maximum efficiency was also decreased which is attributed to an increase of the hydraulic losses due to increasing of number of the blades.

The pressure distribution along streamline midway the hub and shroud of torque converter elements showed that there is an increase of the pressure inside the turbine until the midway span at speed ratio 0.0. Pressure at the exit of the turbine is higher than the pressure at the turbine inlet at this speed ratio.

Increasing the number of the blades decreased the torque ratio at stall; turbine speed equal zero. The torque ratio is also decreased for higher speed ratio (higher than 0.5 ). The flow rate 
of the TC-New is higher than the original GM-245 due to the increase of the number of the blades.

Increasing the number of blades of both pump and turbine

- Increase the torque

- Decrease the torque ratio

- Decrease the maximum efficiency

- Decrease the coupling point

- Decrease the minimum pressure (and hence the probality of cavitation)

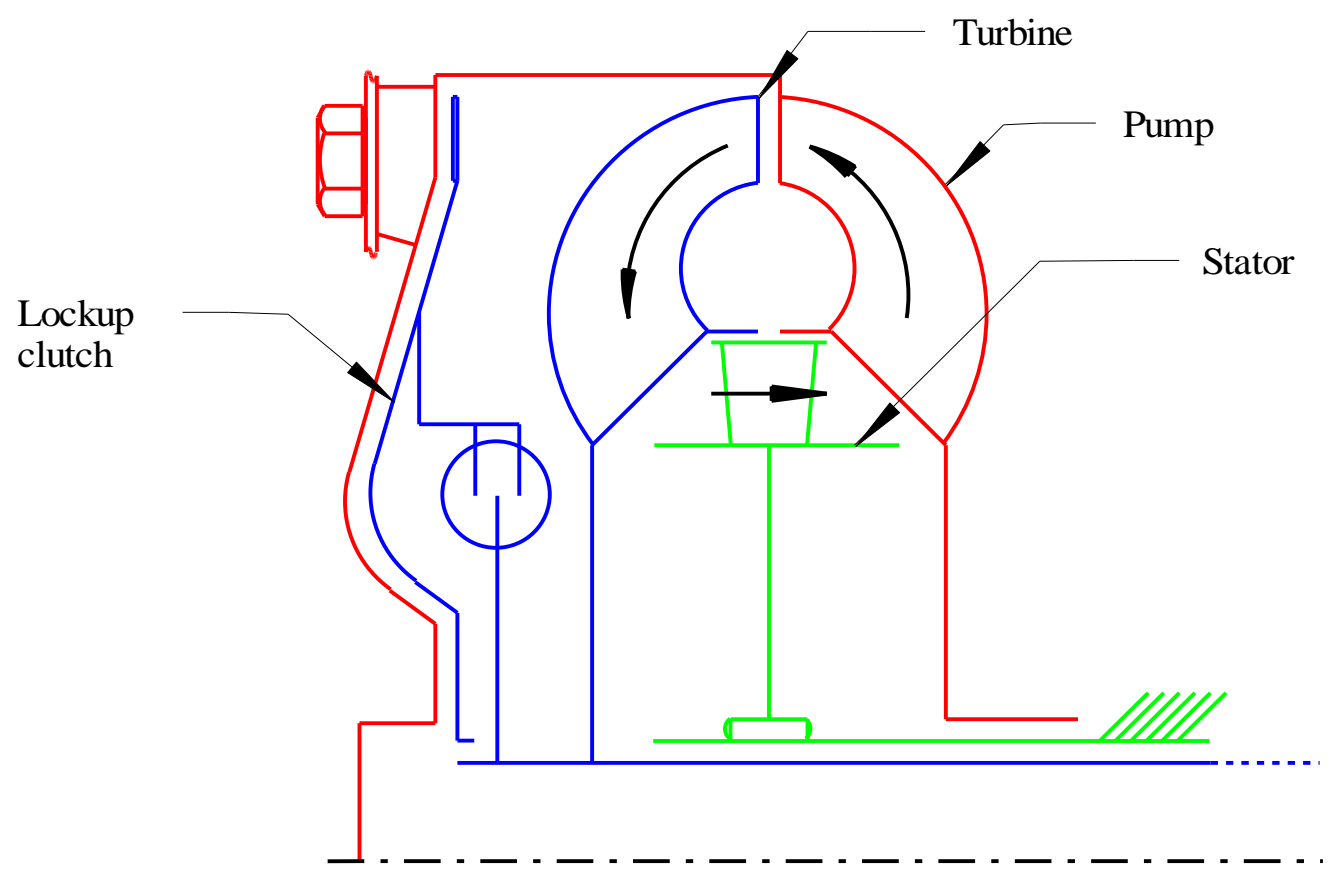

Figure 1: Schematic cross section of a torque converter 


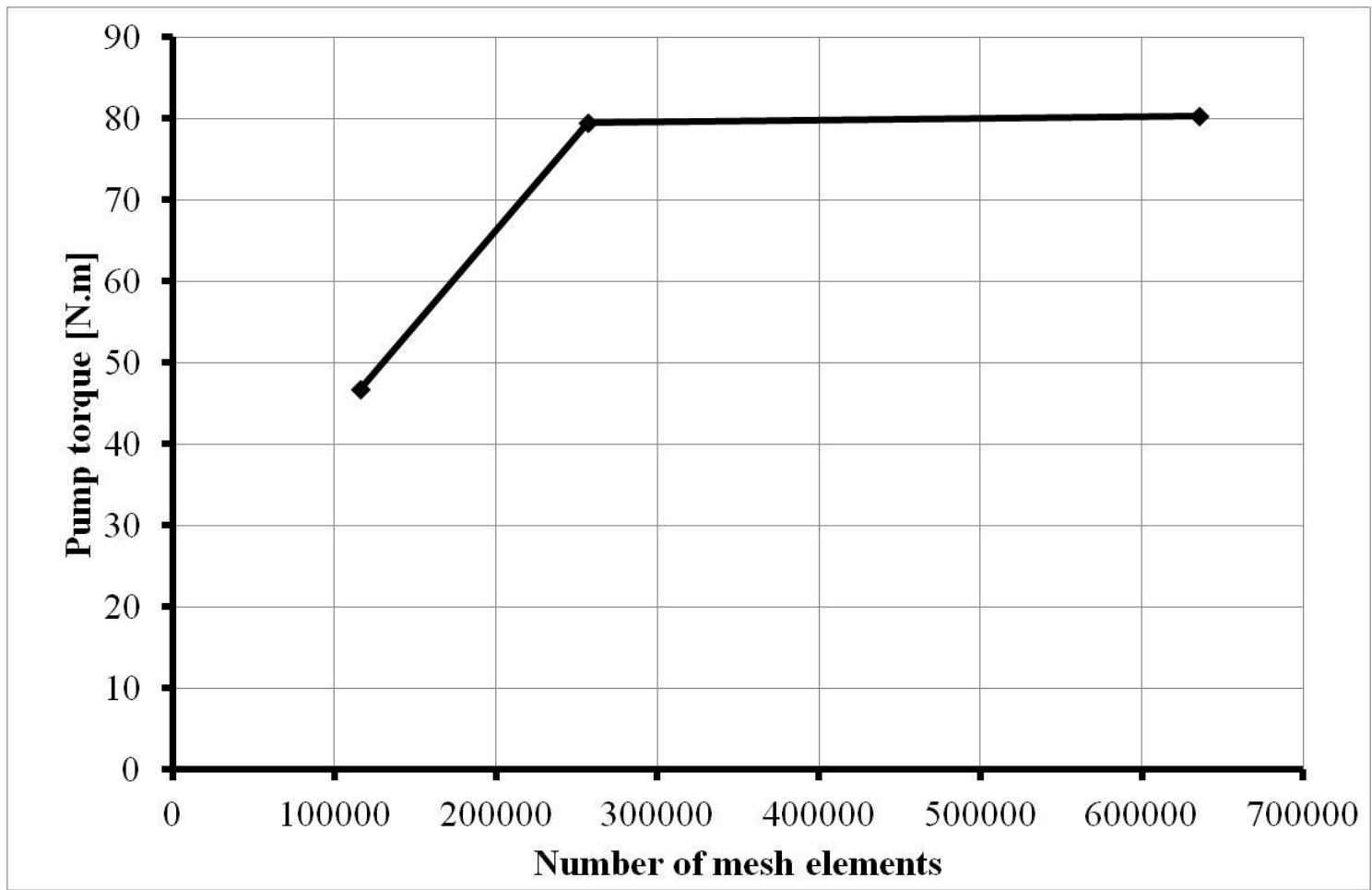

Figure 2: Pump torque for different grid size for (GM-245) torque converter

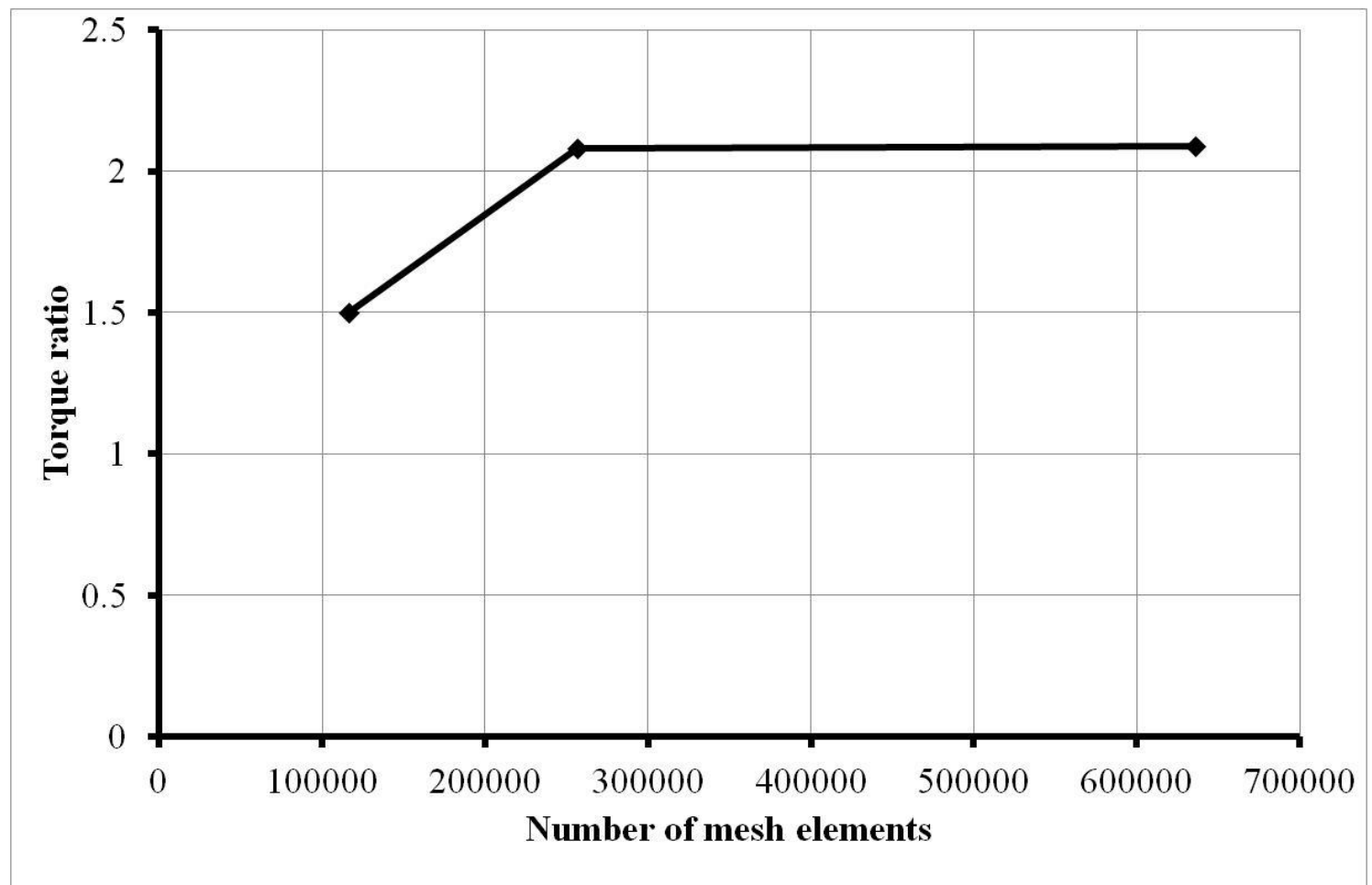

Figure 3: Torque ratio for different grid size for (GM-245) torque converter 


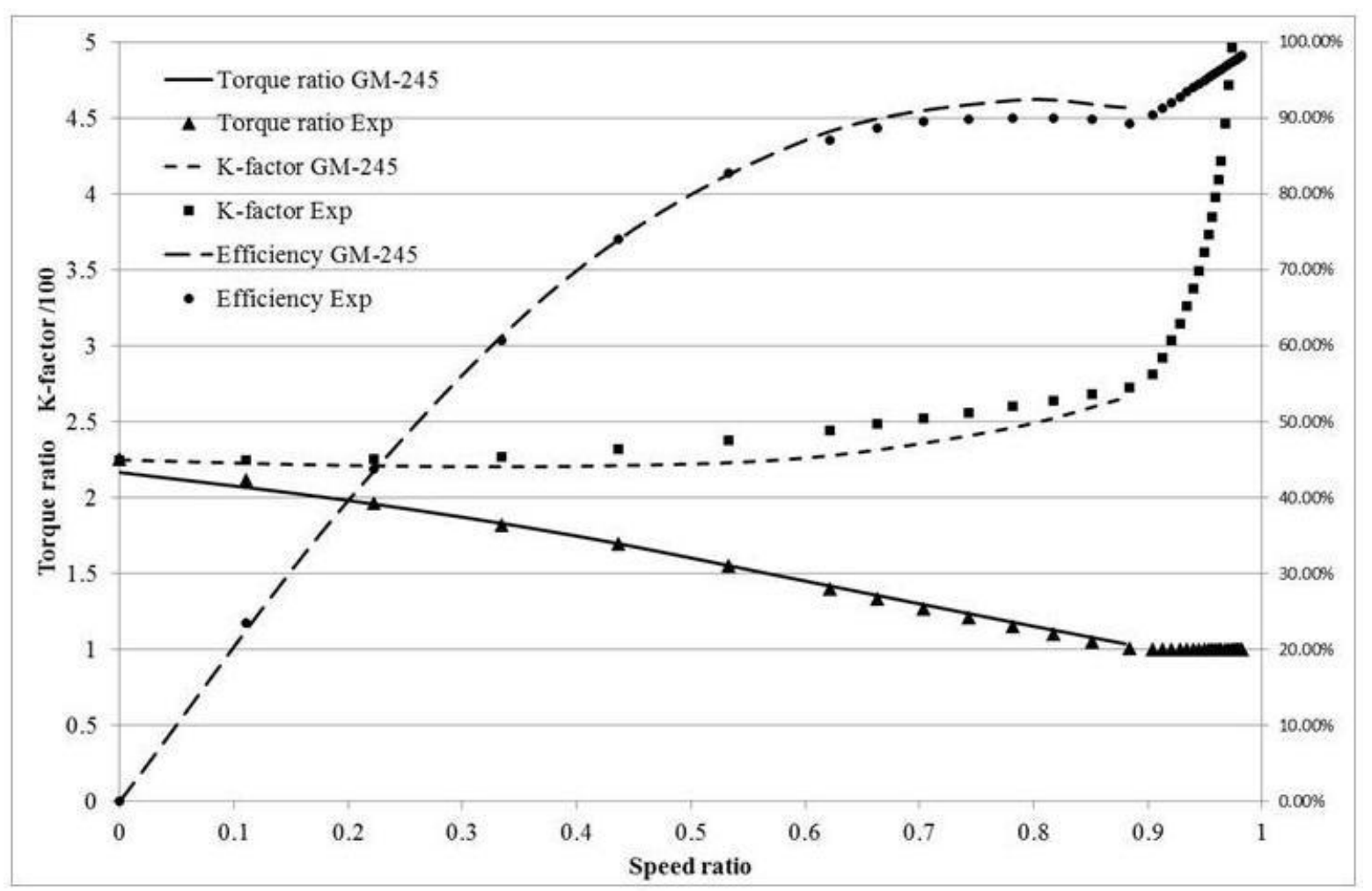

Figure 4: Torque converter GM-245 performance characteristics comparison between experimental and numerical solution

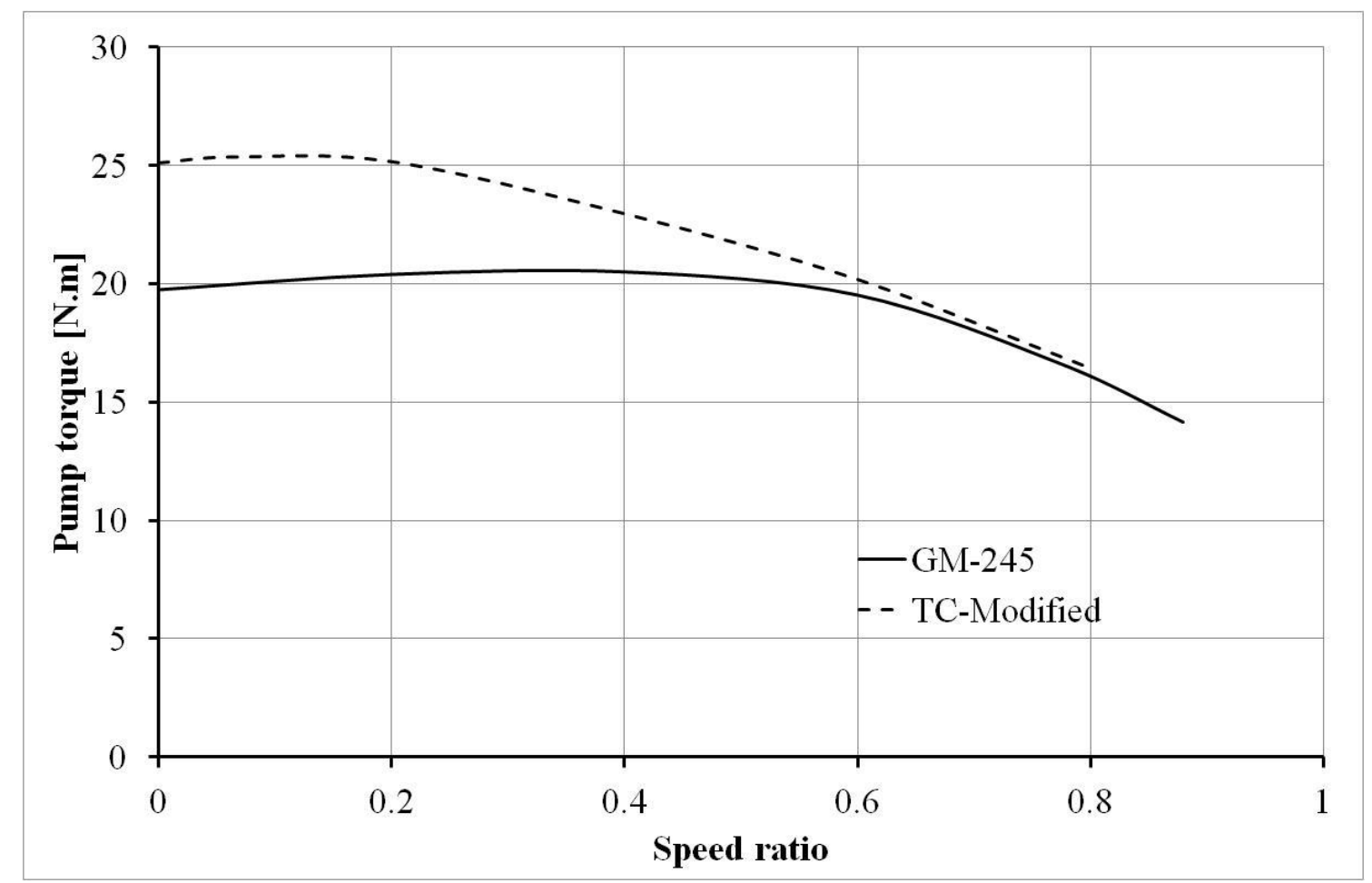

Figure 5: Pump torque against speed ratio for two torque converters 


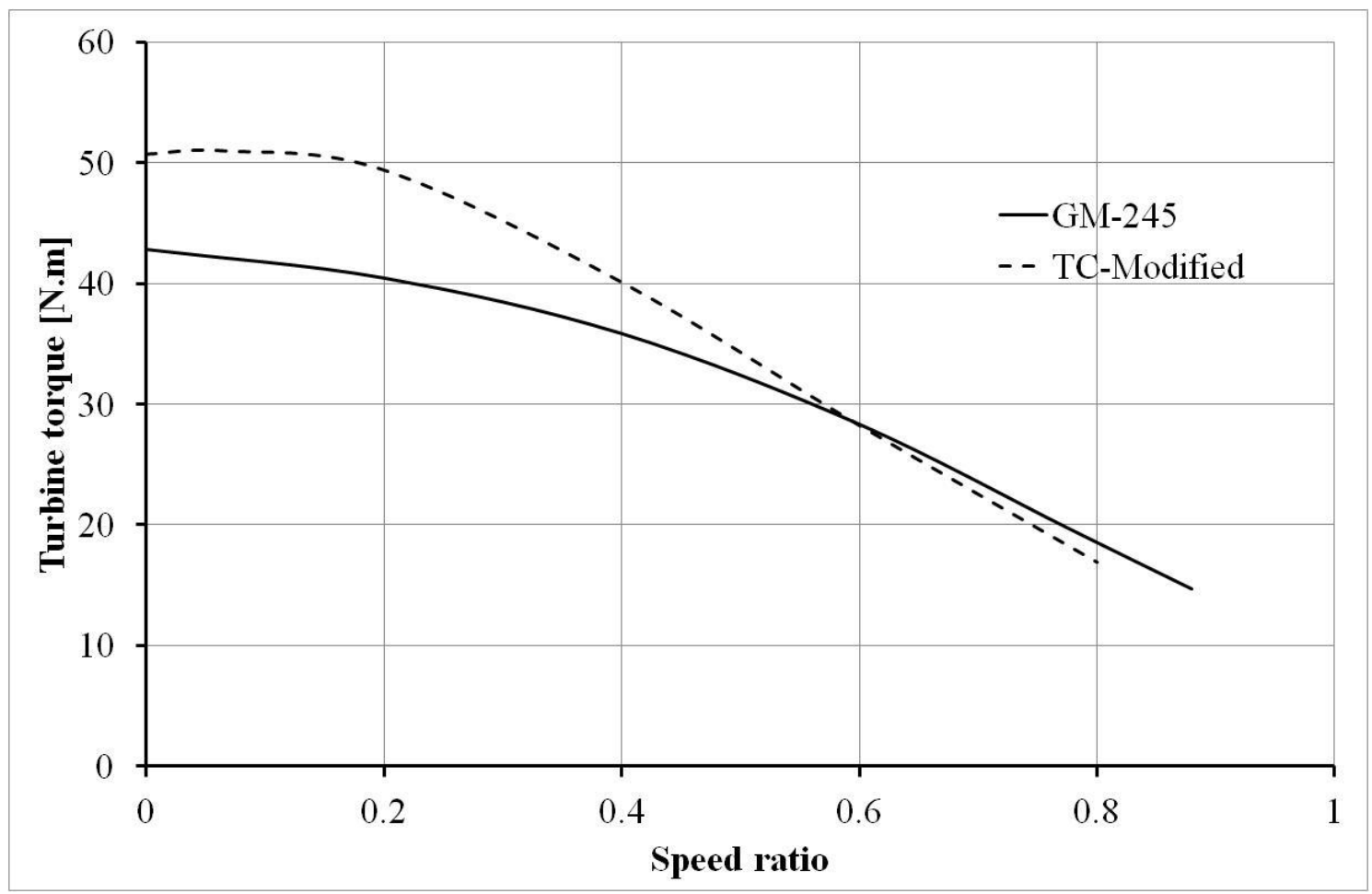

Figure 6: Turbine torque against speed ratio for two torque converters

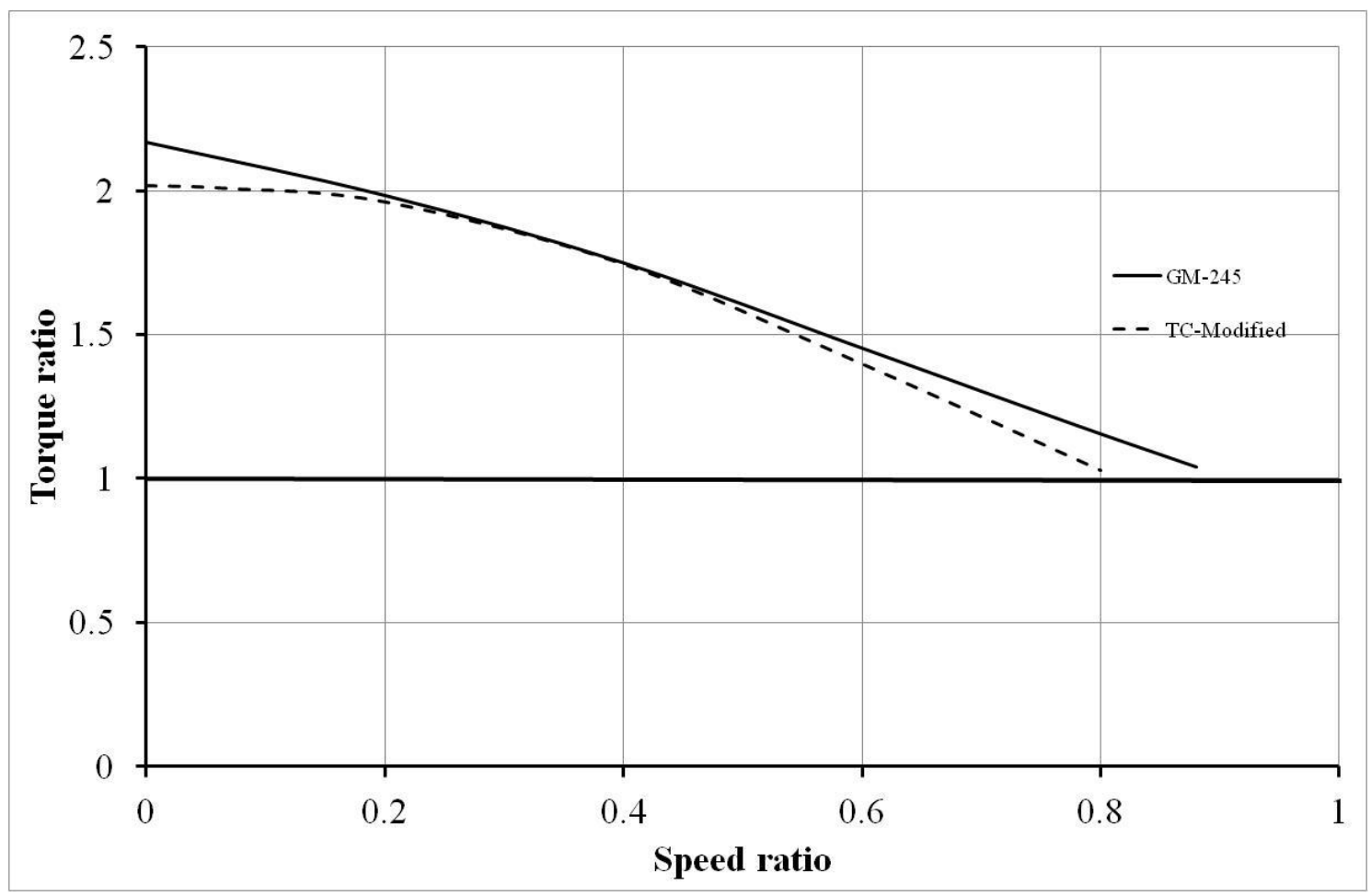

Figure 7: Torque ratio comparison 


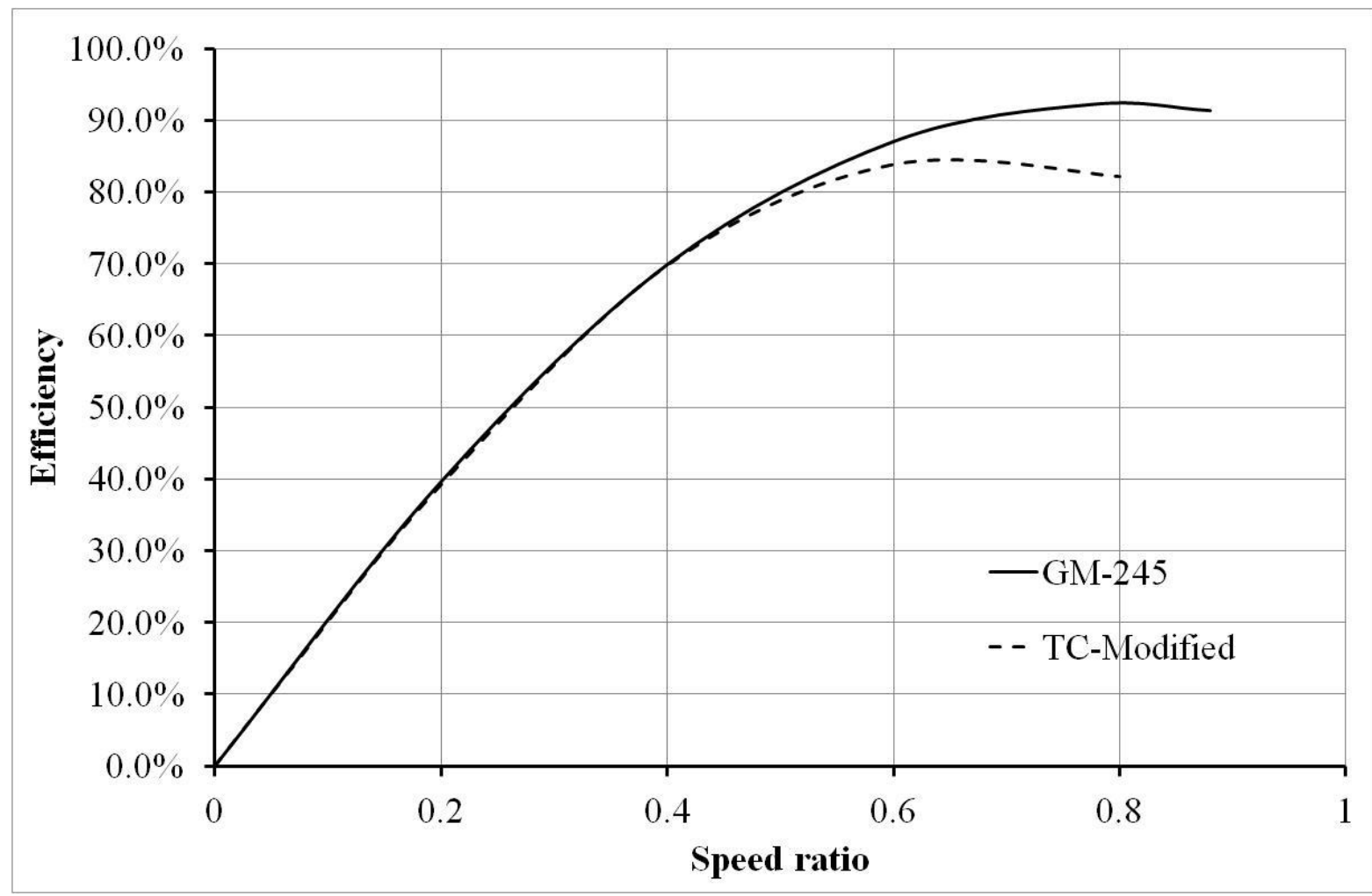

Figure 8: Efficiency comparison

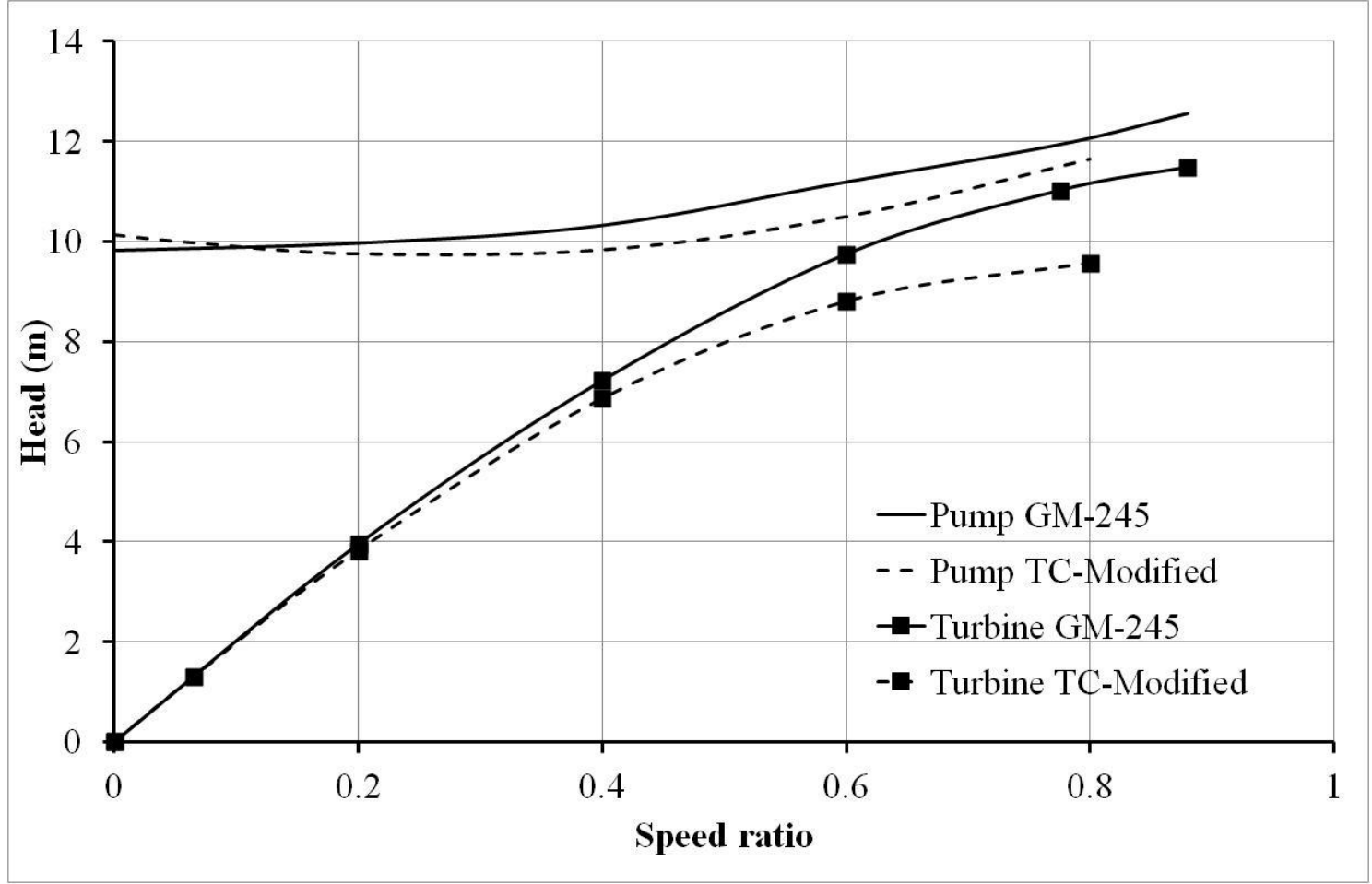

Figure 9: Pump and turbine head against speed ratio 


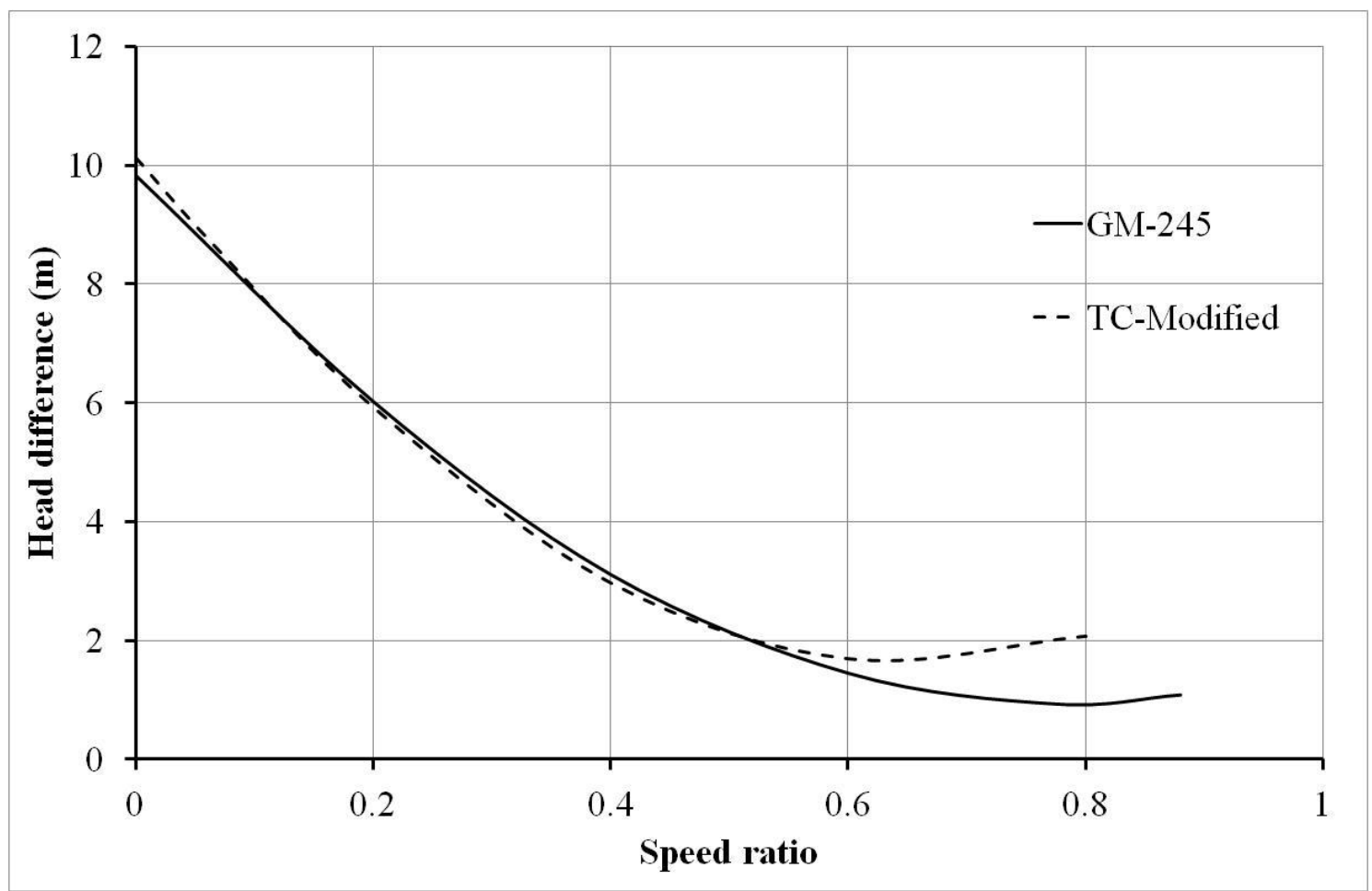

Figure 10: Head difference against speed ratio

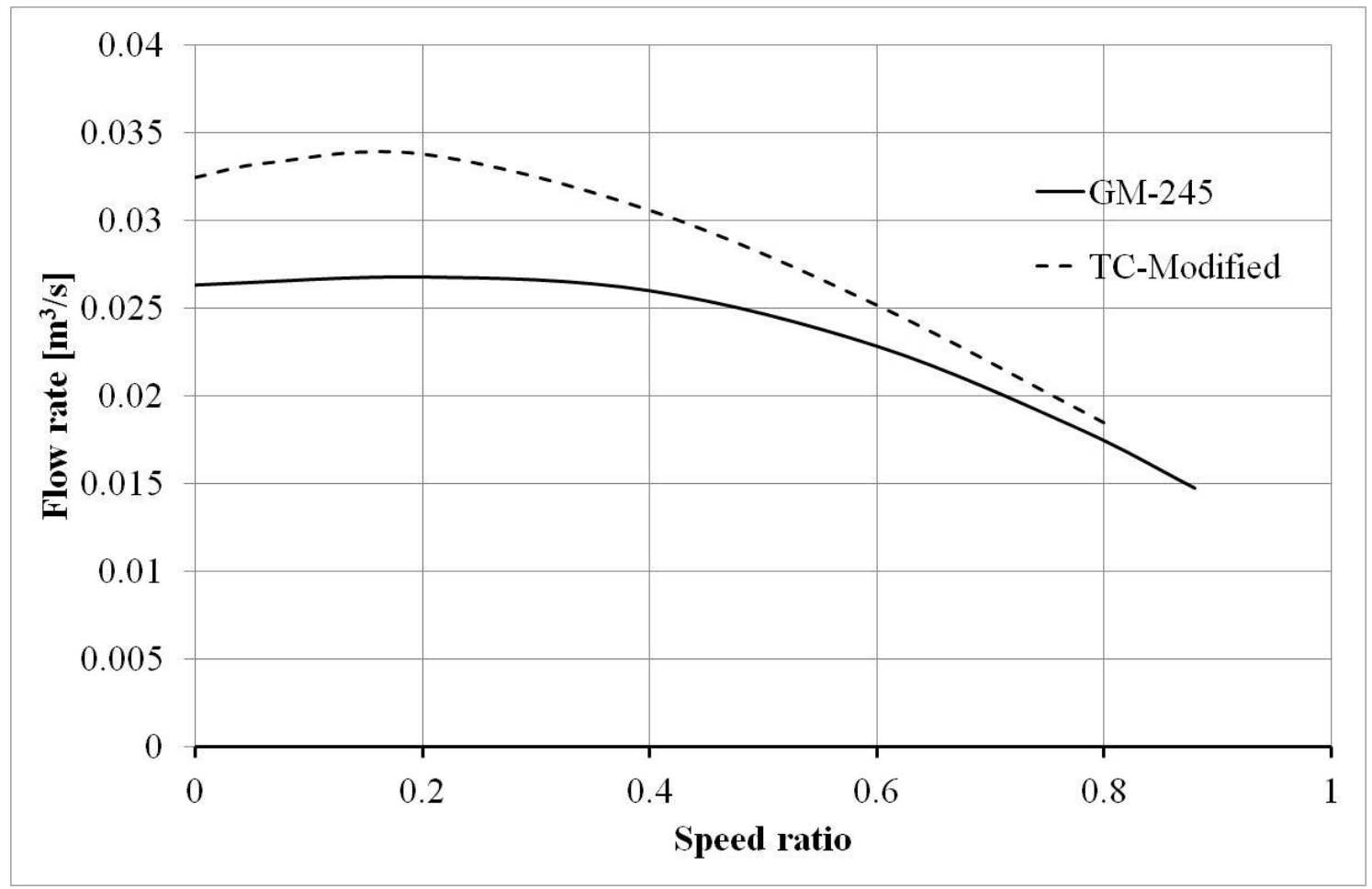

Figure 11: Flow rate across torque converters 


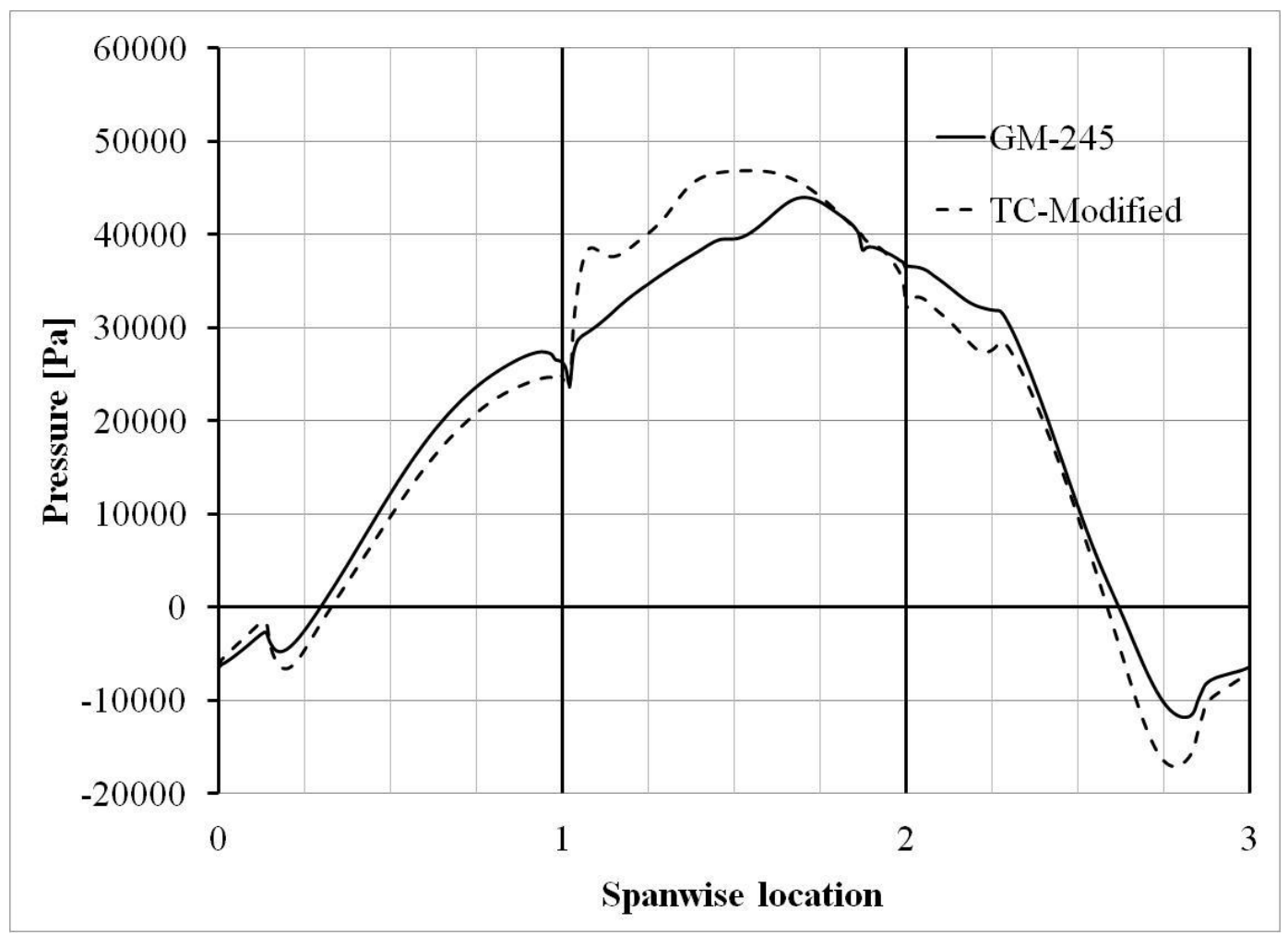

Figure 12: Pressure distribution along a streamline midway between hub and shroud inside the two torque converters at speed ratio 0.0

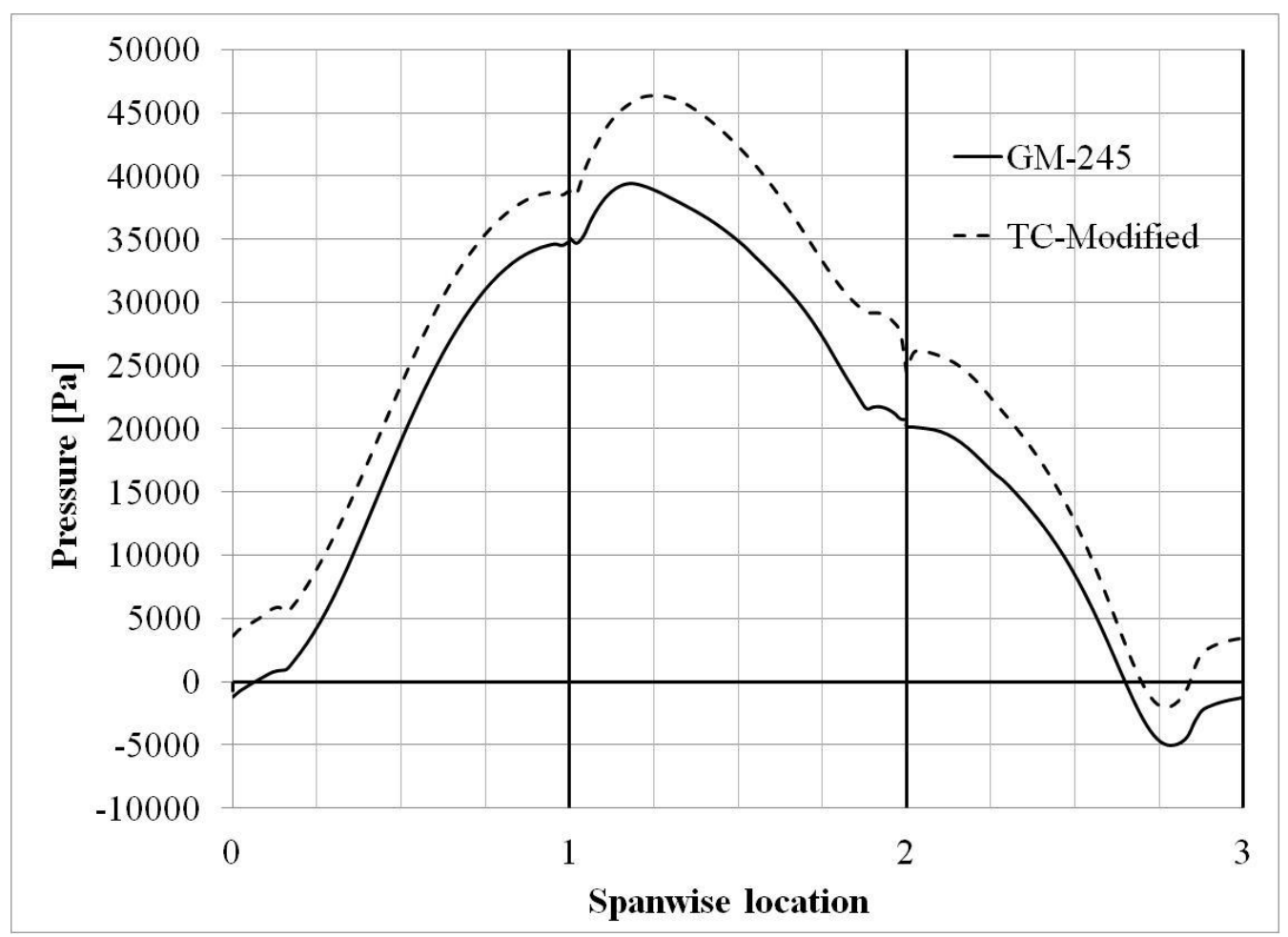

Figure 13: Pressure distribution along a streamline midway between hub and shroud inside the two torque converters at speed ratio 0.6 


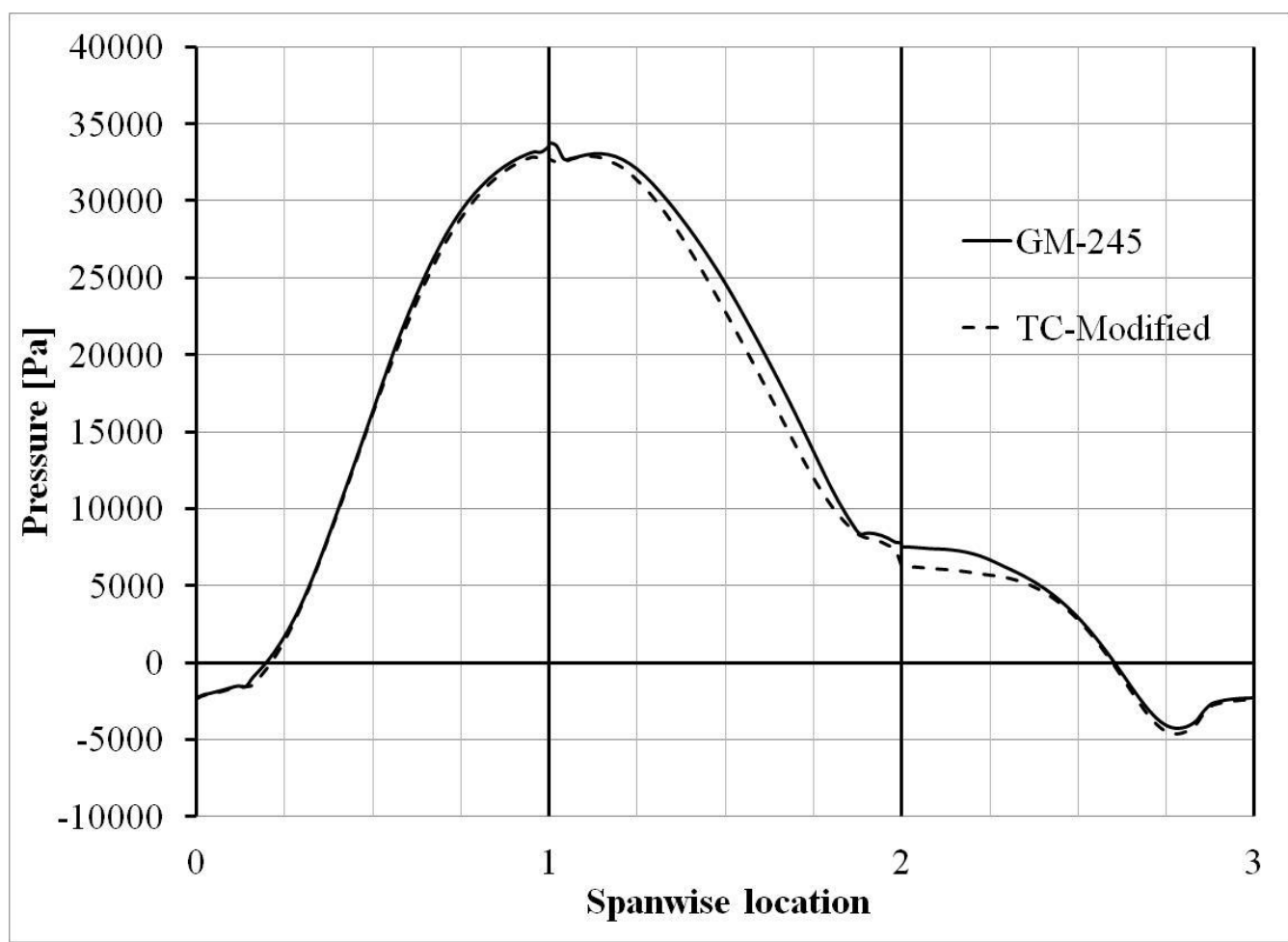

Figure 14: Pressure distribution along a streamline midway between hub and shroud inside the two torque converters at speed ratio 0.8 


\section{REFRENCES}

1. By, R.R. and B. Lakshminarayana, Measurement and Analysis of Static Pressure Field in a Torque Converter Pump. Journal of Fluids Engineering, 1995. 117(1): p. 109-115.

2. By, R.R. and B. Lakshminarayana, Measurement and Analysis of Static Pressure Field in a Torque Converter Turbine. Journal of Fluids Engineering, 1995. 117(3): p. 473-478.

3. Brun, K. and R.D. Flack, Laser velocimeter measurements in the turbine of an automotive torque converter: Part I: Average measurements. Journal of turbomachinery, 1997. 119: p. 646-654.

4. Fujitani, K., R. Himeno, and M. Takagi, Computational Study on Flow through a Torque Converter. SAE Technical Paper 881746, 1988.

5. Abe, K., Kondoh, T., Fukumura, K., and Kojima, M., , ThreeDimensional Simulation of the Flow in a Torque Converter. SAE Technical Paper No. 910800, 1991.

6. By, R.R., B. Lakshminarayana, and R. Kunz, Navier-Stokes Analysis of the Pump Flow Field of an Automotive Torque Converter. Journal of Fluids Engineering, 1995. 117(1): p. 116-122.

7. Cigarini, M. and S. Jonnavithula, Fluid Flow in an Automotive Torque Converter: Comparison of Numerical Results with Measurements. SAE Technical Paper 950673, 1995.

8. Dale, M., Applied torque converters. Schilling, Jim (ed.), The Wisconsin engineer, 1957. 62(3): p. 18-23.

9. Schweitzer, J. and J. Gandham, Computational Fluid Dynamics in Torque Converters: Validation and Application. International Journal of Rotating Machinery, 2003. 9(6): p. 411-418. 